\title{
REVIEW
}

\section{Electrolyzed water and its application in animal houses}

\author{
Weichao ZHENG, Li NI, Baoming LI (凶)
}

Key Lab of Agricultural Engineering in Structure and Environment, Ministry of Agriculture/Beijing Engineering Research Center on Animal Healthy Environment/College of Water Resources \& Civil Engineering, China Agricultural University, Beijing 100083, China

\begin{abstract}
Electrolyzed water (EW) can be produced by electrolysis of a dilute salt solution. Slightly acidic electrolyzed water (SAEW, $\mathrm{pH}$ 5.0-6.5) and neutral electrolyzed water (NEW, $\mathrm{pH}$ 6.5-8.5) are considered healthy and environmentally friendly because no hazardous chemicals are added in its production, there is reduced corrosion of surfaces and it minimizes the potential for damage to animal and human health. Over the last decade, EW has become increasingly popular as an alternative disinfectant for decontamination in animal houses. However, there have been some issues related to EW that are not well known, including different mechanisms for generation of SAEW and NEW, and the antimicrobial mechanism of EW. This review covers the definitions of SAEW and NEW, different generation systems for SAEW and NEW, the antimicrobial mechanism of EW, and recent developments related to the application of SAEW and NEW in animal houses.
\end{abstract}

Keywords disinfection, poultry and livestock, slightly acidic electrolyzed water, neutral electrolyzed water

\section{Introduction}

The environment within animal houses is often contaminated with pathogenic microorganisms and contaminated surfaces in such facilities may act as reservoirs for pathogenic microorganisms ${ }^{[1-3]}$. Exposure to high levels of airborne microbes in animal houses can have negative impacts on the health of both the animals and the workers $^{[4-7]}$. Microorganisms contaminating animal houses are also responsible for disease infection among animals $^{[8,9]}$ and can even enter the food chain ${ }^{[10,11]}$. Provision of healthy environments for animal production is receiving increased attention.

Received April 28, 2016; accepted July 1, 2016

Correspondence: libm@cau.edu.cn
Disinfection is a commonly recommended approach for disease prevention in animal houses ${ }^{[12-15]}$. This can help to lower the potential for disease infection and transmission in animal houses by reducing the population of pathogenic microorganisms on the surfaces or in the air. Numerous chemical disinfectants such as benzalkonium chloride, formaldehyde and glutaraldehyde are used for disinfection against bacterial infections in animal houses ${ }^{[16]}$. However, the use of these chemical disinfectants has limited potential due to their toxicity, corrosiveness and/or volatility ${ }^{[17]}$. Also, the resistance and cross-resistance of pathogens to chemical disinfectants has been reported ${ }^{[18,19]}$. Therefore, it is essential to develop alternative disinfectants for decontamination in animal houses.

Electrolyzed water (EW) has been regarded as a novel sanitizer in recent years. Acidic electrolyzed water (AEW, $\mathrm{pH}<2.7$ ), slightly acidic electrolyzed water (SAEW $\mathrm{pH}$ 5.0-6.5) and neutral electrolyzed water (NEW, 6.5-8.5) are the three main types of EWs reported as alternative disinfectants for decontamination. AEW has been reported to be an effective antimicrobial agent in the food industry ${ }^{[20-22]}$. However, AEW can easily release $\mathrm{Cl}_{2}$ gas due to its volatility, which causes chlorine loss, thus decreasing AEW bactericidal activity over time ${ }^{[23,24]}$. The strong acidity $(\mathrm{pH}<2.7)$ of AEW can also cause corrosion of equipment ${ }^{[25]}$. These disadvantages potentially limit the use of AEW in some applications such as animal houses. In contrast, SAEW and NEW are near neutral $\mathrm{pH}$ and more stable than $\mathrm{AEW}^{[24]}$. They have been increasingly used for the prevention and control of microorganisms ${ }^{[22,26-28]}$. SAEW and NEW are considered healthy and environmentally friendly because no hazardous chemicals are added in its production, they cause less corrosion of surfaces and minimize the potential for damage to animal and human health ${ }^{[25,29,30]}$. For these reasons, SAEW and NEW may be alternative disinfectants for decontamination in animal houses. A considerable number of studies have reported the increased use of SAEW and NEW for controlling contamination in animal houses, including facilities for swine, poultry and diary ${ }^{[1-3,15,31-35]}$. This review covers 
some important aspects of SAEW/NEW, including definition, generation, microorganism inactivation and applications in animal houses.

\section{Electrolyzed water (EW)}

Electrolyzed water (EW) was initially used for inactivation of pathogens in health care facilities in Japan. AEW, also known as electrolyzed oxidizing water, is produced by electrolysis of a dilute salt solution in an electrolytic cell, within which the anode and cathode are separated by a membrane. By subjecting the electrodes to direct current voltages, negatively charged ions such as chloride and hydroxide move to the anode to give up electrons and become gaseous oxygen $\left(\mathrm{O}_{2}\right)$ and chlorine $\left(\mathrm{Cl}_{2}\right)$, hypochlorite ions $\left(\mathrm{OCl}^{-}\right)$, hypochlorous acid $(\mathrm{HOCl})$ and hydrochloric acid $(\mathrm{HCl})$. Concurrently, positively charged ions, such as hydrogen and sodium, move to the cathode to take up electrons and become hydrogen gas $\left(\mathrm{H}_{2}\right)$ and sodium hydroxide $(\mathrm{NaOH})^{[36]}$. As a result, AEW with low $\mathrm{pH}$ and available chlorine is produced at the anode. Alkaline EW, also called electrolyzed reduced water with high $\mathrm{pH}(10.0-11.5)$ is produced at the cathode. The principle of producing AEW can be described with the following:

$$
\begin{gathered}
\text { Anode }: 2 \mathrm{H}_{2} \mathrm{O}-4 \mathrm{e}^{-} \rightarrow 4 \mathrm{e}^{+}+\mathrm{O}_{2} \uparrow \\
2 \mathrm{Cl}^{-}-2 \mathrm{e}^{-} \rightarrow \mathrm{Cl}_{2} \uparrow \\
\mathrm{Cl}_{2}+\mathrm{H}_{2} \mathrm{O} \rightarrow \mathrm{H}^{+}+\mathrm{Cl}^{-}+\mathrm{HOCl} \\
\mathrm{HOCl} \rightarrow \mathrm{H}^{+}+\mathrm{OCl}^{-} \\
\text {Cathode }: 2 \mathrm{H}_{2} \mathrm{O}+2 \mathrm{e}^{-} \rightarrow 2 \mathrm{OH}^{-}+\mathrm{H}_{2} \uparrow
\end{gathered}
$$

Scientists have given various names to $\mathrm{EW}$ with a $\mathrm{pH}$ of 5.0-6.5, but none of these names has been universally adopted. Most studies have defined EW with a pH of 5.06.5 as $\mathrm{SAEW}^{[1-3,15,28,33,37-57]}$. However, it has also been called electrolyzed neutral water ${ }^{[58]}$, near-neutral electrolyzed oxidizing water ${ }^{[25,59]}$ and $\mathrm{NEW}^{[24,48,60,61]}$. It is important to distinguish SAEW and NEW using an agreed standard. In this review, EW with a pH of 5.0-6.5 and 6.58.5 are defined as SAEW and NEW, respectively.

Available chlorine, also called free chlorine, has been considered to be the active component of EW responsible for its bactericidal activity. The $\mathrm{pH}$ of $\mathrm{EW}$ is important in the formation of various chlorine species. The relative levels or proportions of available chlorine compounds $\left(\mathrm{Cl}_{2}, \mathrm{HOCl}\right.$ and $\left.\mathrm{OCl}^{-}\right)$in EW are $\mathrm{pH}$ dependent ${ }^{[21,23,38]}$. Bactericidal activity of $\mathrm{HOCl}$ is much higher than that of $\mathrm{OCl}^{[21,38]}$. The highest proportion of $\mathrm{HOCl}$ of $\mathrm{EW}$ was found to be generated at around $\mathrm{pH} 4-5$. $\mathrm{More}^{\mathrm{Cl}_{2}}$ was generated from $\mathrm{HOCl}$ at a lower $\mathrm{pH}$, whereas more $\mathrm{OCl}^{-}$ was generated from $\mathrm{HOCl}$ at a higher $\mathrm{pH}^{[23]}$. At $\mathrm{pH} 5.0$ 6.5 , the effective form of chlorine in SAEW is mostly $\mathrm{HOCl}$, which has been shown to have strong antimicrobial activity ${ }^{[3,37,62]}$. For NEW with $\mathrm{pH} 6.5-8.5$, the effective form of chlorine is mainly $\mathrm{OCl}^{-}$. Therefore, SAEW was reported to have a higher bacterial activity than NEW at the same available chlorine concentration (ACC) ${ }^{[46]}$. The available chlorine and its proportion in SAEW and NEW is considered to be the main factor affecting their antimicrobial activity.

\section{Generation systems for SAEW and NEW}

The principles of producing SAEW and NEW are the same as AEW, but their generation systems are modified to reach the desired $\mathrm{pH}$. SAEW has been reported to be produced by electrolysis of dilute $\mathrm{NaCl}$ and/or hydrochloric acid solutions in an electrolysis cell without a membrane ${ }^{[15,38,63]}$, or by redirecting the product formed at the cathode into the anode chamber while electrolyzing a dilute $\mathrm{NaCl}$ solution in a cell with a separating membrane ${ }^{[25]}$. NEW has been reported to be produced by electrolyzing a dilute $\mathrm{NaCl}$ solution in an electrolysis cell without membrane with or without dilution with tap water after electrolysis ${ }^{[27,32]}$, or by redirecting the product formed at the cathode into the anode chamber while electrolyzing a dilute $\mathrm{NaCl}$ solution in a cell with a separating membrane ${ }^{[64]}$. Production systems for generating SAEW and NEW described in previous studies are shown in Table 1.

One common system is to generate SAEW by electrolysis of a dilute $\mathrm{HCl}$ solution in a non-membrane electrolytic cell, then the highly concentrated $\mathrm{HOCl}$ produced is diluted with tap water ${ }^{[38]}$. The electrolyte in this system is a dilute $\mathrm{HCl}$ solution, but a $\mathrm{NaCl}$ solution can also be used as the electrolyte ${ }^{[39,45,63]}$. The SAEW generated in this system usually has a low ACC (5$50 \mathrm{mg} \cdot \mathrm{L}^{-1}$, preferably $20-30 \mathrm{mg} \cdot \mathrm{L}^{-1}$ ), but most of the available chlorine is present as $\mathrm{HOCl}^{[24,38,46]}$. This system has been widely employed to generate SAEW with a low ACC for decontamination in the food industry. Another system is to generate $\mathrm{SAEW}$ by electrolyzing dilute $\mathrm{NaCl}$ and $\mathrm{HCl}$ solutions in a non-membrane electrolytic cell. In this system, $\mathrm{NaCl}$ provides most of the $\mathrm{Cl}^{-}$to generate available chlorine, and $\mathrm{HCl}$ is mainly to adjust the $\mathrm{pH}$ to 5.0-6.5. $\mathrm{HCl}$ solution can also be added after electrolyzing a dilute $\mathrm{NaCl}$ solution to adjust the $\mathrm{pH}^{[33,79,80]}$. Zheng et al. ${ }^{[46]}$ reported that the available chlorine composition was similar for SAEW generated by adding $\mathrm{HCl}$ solution either before or after electrolyzing a dilute $\mathrm{NaCl}$ solution. Using this system, SAEW with a large range of ACC was generated, from 0.5 to $400 \mathrm{mg} \cdot \mathrm{L}^{-1}[1,2,15,41,54,68,69]$. NEW is produced when a dilute $\mathrm{NaCl}$ solution is electrolyzed in a 
Table 1 Types of generation systems for SAEW and NEW

\begin{tabular}{|c|c|c|c|}
\hline Electrolyzed water & Electrolyte/Electrolytic cell & Generation mechanism & References \\
\hline$\overline{\text { SAEW }}$ & $\mathrm{HCl} /$ Non-membrane & $\begin{array}{l}\text { Dilute } \mathrm{HCl} \text { or } \mathrm{NaCl} \text { solution is electrolyzed in a non- } \\
\text { membrane electrolytic cell to produce highly concentrated } \\
\mathrm{HOCl} \text {, which is then diluted with tap water. }\end{array}$ & {$[28,37,38,40,43,44,47,51-53,55,57,65-67]$} \\
\hline SAEW & $\mathrm{NaCl}$ and $\mathrm{HCl} /$ Non-membrane & $\begin{array}{l}\text { Dilute } \mathrm{NaCl} \text { and } \mathrm{HCl} \text { solution is electrolyzed in a non- } \\
\text { membrane electrolytic cell. }\end{array}$ & {$[1,2,15,41,54,61,68,69]$} \\
\hline NEW & $\mathrm{NaCl} /$ Non-membrane & $\begin{array}{l}\text { Dilute } \mathrm{NaCl} \text { solution is electrolyzed in a non-membrane } \\
\text { electrolytic cell. }\end{array}$ & {$[60,70-73]$} \\
\hline NEW & $\mathrm{NaCl} /$ Non-membrane & $\begin{array}{l}\text { Dilute } \mathrm{NaCl} \text { solution is electrolyzed in a non-membrane } \\
\text { electrolytic cell to produce } \mathrm{EW} \text { with highly available } \\
\text { chlorine, which is then diluted with tap water. }\end{array}$ & {$[26,27,29,32,74,75]$} \\
\hline SAEW or NEW & $\mathrm{NaCl} / \mathrm{Membrane}$ & $\begin{array}{l}\text { Dilute } \mathrm{NaCl} \text { solution is electrolyzed in an electrolytic cell } \\
\text { with a membrane. A certain proportion of the Alkaline } \\
\text { EW formed at the cathode chamber is redirected into the } \\
\text { anode chamber. }\end{array}$ & {$[25,34,46,64,76-78]$} \\
\hline
\end{tabular}

Note: SAEW, slightly acidic electrolyzed water; NEW, neutral electrolyzed water; EW, electrolyzed water.

non-membrane electrolytic cell. One system is to produce NEW with a desired ACC directly. The other system is to produce EW with highly concentrated available chlorine that is then diluted with tap water to NEW, as is done with chemical sanitizers. AEW is produced by electrolysis of a dilute salt solution in an electrolytic cell, within which the anode and cathode are separated by a membrane. This system for generating AEW can also be used to produce SAEW and NEW, by redirecting the product formed at the cathode into the anode chamber. SAEW or NEW is produced depending on the mixing proportion of the electrolyzed reduced water formed at the cathode and the AEW formed at the anode. Different systems can produce SAEW/NEW with different properties. Even at the same $\mathrm{pH}$ and $\mathrm{ACC}$, the active components of EW can be different ${ }^{[46]}$. The generation mechanism can be an important factor affecting the active components of SAEW and NEW, and thus their antimicrobial activities.

\section{Antimicrobial activities of SAEW and NEW}

SAEW is promoted as a highly effective, healthy and environmentally friendly disinfectant for the food industry ${ }^{[25,37,38,44,81]}$. It has been reported to possess high antimicrobial activity against a broad spectrum of microorganisms, including Bacillus cereus $^{[52]}$, Bacillus subtilis $^{[42]}$, Escherichia coli ${ }^{[40,41,43,44,61,65,68]}$, Listeria monocytogenes $^{[45,67]}$, Salmonella enteritidis ${ }^{[37,46,67,68]}$, Salmonella $\mathrm{spp}^{[44]}$, Staphylococcus aureus ${ }^{[40,41]}$, Vibrio vulnificus and Vibrio parahemolyticus ${ }^{[81,82]}$, mold and yeast ${ }^{[3]}$, porcine reproductive and respiratory syndrome virus, and pseudorabies virus ${ }^{[49]}$. The antimicrobial activity of SAEW relies on its available chlorine, primarily $\mathrm{HOCl}$, which has strong antimicrobial activity ${ }^{[23,30,46,62]}$.

NEW has also been employed to inactivate a variety of microorganisms, including Alicyclobacillus acidoterrestris spores $^{[78]}$, B. subtilis ${ }^{[75]}$, E. coli ${ }^{[26,29,46,72-75]}$, Erwinia carotovora $^{[27]}$, L. monocytogenes ${ }^{[26,27,29,74]}$, Monilinia fructicola and Botrytis cinerea ${ }^{[83]}$, Salmonella $\operatorname{spp}^{[27,46,73,74]}, S$. aureus ${ }^{[2,29]}$, Pseudomonas aeruginosa ${ }^{[26,29]}, V$. vulnificus and $V$. parahemolyticus ${ }^{[72]}$, Fusarium spp $^{[60]}$. and avian influenza viruses ${ }^{[84]}$. The antimicrobial activity of NEW relies on its available chlorine. Compared to SAEW, more available chlorine is present as $\mathrm{OCl}^{-}$when $\mathrm{HOCl}$ is converted to $\mathrm{OCl}^{-}$with an increased $\mathrm{pH}^{[46]}$.

Bacteria can generally grow in the $\mathrm{pH}$ range of SAEW and NEW. The $\mathrm{pH}$ is important in the antimicrobial activities of SAEW and NEW, mainly by influencing the formation of various available chlorine species. Understanding the antimicrobial mechanism of EW is crucial to enable better utilization of EW as an antimicrobial agent. However, little information has been published to explain the antimicrobial mechanism of EW. In general, it is well known that available chlorine compounds are responsible for the antimicrobial activity of EW. Other oxidants, such as the reactive oxygen species (ozone and hydrogen peroxide), generated during electrolysis, are also considered to contribute to the antimicrobial activity of $\mathrm{EW}^{[85,86]}$. Some researchers have suggested that high oxidation-reduction potential (ORP) of AEW contributes to its high antimicrobial activity ${ }^{[87,88]}$. The oxidation, resulting from the high ORP of AEW, probably damages cell membranes and disrupts cell metabolic processes. However, SAEW and NEW have been employed to inactive a variety of microorganisms, even without a high ORP, such as AEW (ORP $>1100 \mathrm{mV}$ ). Koseki et al. ${ }^{[89]}$ reported that the higher ORP of ozonized water did not give a higher antimicrobial effect than the lower ORP of EW. This suggests that high ORP is not the determining factor in the antimicrobial activity of EW. It also has been noted that the low $\mathrm{pH}$ of AEW may reduce bacterial 
growth and sensitize the outer membrane of bacterial cells to the entry of active compounds ${ }^{[90,91]}$.

Feliciano et al. ${ }^{[92]}$ investigated the structural changes to E. coli and Listeria innocua cells treated with AEW and NEW by transmission electron microscopic analysis. Exposure to AEW and NEW decreased the integrity of the cell envelope and caused aggregation of the cytoplasmic components. Similar structural damage to E. coli O157:H7 and $S$. aureus by SAEW has been reported ${ }^{[41]}$. The research on disinfection mechanisms conducted by Zeng et al. ${ }^{[93]}$ revealed that AEW could rapidly decrease the dehydrogenase activities of E. coli and $S$. aureus, resulting in inhibition of respiration and anabolism. AEW exposure can increase the membrane permeability of the cells and cause leakages of intracellular DNA, $\mathrm{K}^{+}$and proteins, and some intracellular proteins are destroyed. Several studies have shown that $\mathrm{HOCl}$ penetrates bacterial cell membranes and produces hydroxyl radicals ${ }^{[94-96]}$. These radicals are known to exert antimicrobial activity by causing the oxidation of key metabolic systems in bacteria $^{[21]}$. Fukuzaki ${ }^{[97]}$ developed a model to explain the antimicrobial mechanism of sodium hypochlorite. This model suggest that the antimicrobial activity of EW is governed by $\mathrm{HOCl}$ and $\mathrm{OCl}^{-}$. The antimicrobial action of $\mathrm{HOCl}$ is attributed to its penetration into microbial cells across the cell walls and membranes. As a result, $\mathrm{HOCl}$ can attack the microbial cell not only from the outside, but also from within the cell. $\mathrm{OCl}^{-}$is unable to penetrate the microbial cell membrane because of the existence of the lipid bilayer, but it can still impose oxidizing action from outside the cell. The microbial cell wall and membrane can thus be ruptured or disintegrated by exposure to $\mathrm{OCl}^{-}$, following the inactivation of functional proteins localized in the plasma membrane. The inhibition of enzyme activity essential for microbial growth, damage to the membrane and DNA, and perhaps deterioration in membrane transport capacity are believed to be responsible for the antimicrobial activity of $\mathrm{HOCl}$ and $\mathrm{OCl}^{-}$, although these factors have not been fully examined ${ }^{[22]}$.

\section{SAEW and application in animal houses}

Animal houses are often contaminated with high concentrations of microorganisms which have multiple adverse environmental and health effects on both animals and workers. Removal of microbial contaminants in animal houses is receiving increased attention. In recent years, spraying or soaking using SAEW or NEW has been introduced to lower the microbial contaminant concentrations in animal houses to prevent diseases, mainly for surface and air disinfection. They are considered as alternative disinfectants for decontamination in animal houses because of their high antimicrobial activity, environmental safety, reduced corrosion of surfaces, and minimization of the potential for damage to animal and human health. SAEW is much more often employed for disinfection in animal houses than NEW.

\subsection{Surface disinfection}

Table 2 illustrates the effectiveness of SAEW in reducing the microbial populations on the surfaces in animal houses. Spraying or flushing using SAEW has proven to be highly effect in reducing microbial populations on the structural and equipment surfaces. Increasing the ACC of SAEW and the spraying or flushing volume can improve the antimicrobial effectiveness on these surfaces. Additionally, Zang et al. ${ }^{[98]}$ reported that cleaning with tap water and spraying SAEW can inactivate $S$. enteritidis on the surface of plastic cages used for poultry transport. The inactivation activity increased with increasing cleaning time, treatment time and ACC of the SAEW. Spraying SAEW is also suggested to be a sanitizing solution for eggshells ${ }^{[37,50]}$. It is reported that SAEW has an equivalent or higher efficiency in reducing E. coli O157:H7, S. aureus, $S$. enteritidis and indigenous microbiota present on eggshells compared to chlorine dioxide and $\mathrm{NaOCl}$ solution, and has similar bactericidal activities with AEW at the same ACC $\left(60-100 \mathrm{mg} \cdot \mathrm{L}^{-1}\right)$. Several researchers have reported that organic matter, such as protein compounds, can reduce the bacterial activity of $\mathrm{EW}^{[3,99-102]}$. Significant amounts of organic matter are usually attached to the structural and equipment surfaces in the animal houses. In addition to increasing the ACC of SAEW and the spraying or flushing volume, cleaning before disinfection can also be employed to improve the antimicrobial effectiveness for these surfaces.

\subsection{Air disinfection}

The sanitizing potential of spraying SAEW on airborne microbes in animal houses is shown in Table 3. The airborne microbial populations in poultry houses increase during in the day. This may be because the continuous movement of birds can lead to more microorganisms in the air ${ }^{[54]}$. The airborne microbial population after spraying SAEW is significantly lower than for the untreated control (Table 3). Spraying SAEW or NEW is suggested to be an efficient approach to reduce airborne bacterial contamination in layer poultry houses. The ability of spraying SAEW to reduce airborne bacterial contamination in a layer house showed a dosage-dependent relationship with the ACC of SAEW and the spraying volume ${ }^{[15,75]}$. Spraying NEW has also been reported to reduce airborne particulate matter to which microbes attach in a layer breeding house ${ }^{[32]}$. When comparing the change in airborne microbial populations after spraying SAEW or water in a layer chamber, Zheng et al. ${ }^{[33]}$ demonstrated that airborne culturable bacteria were reduced more by the bactericidal effect of SAEW than by the reduction in airborne particular matter. In addition to the ACC of SAEW and the spraying volume, 


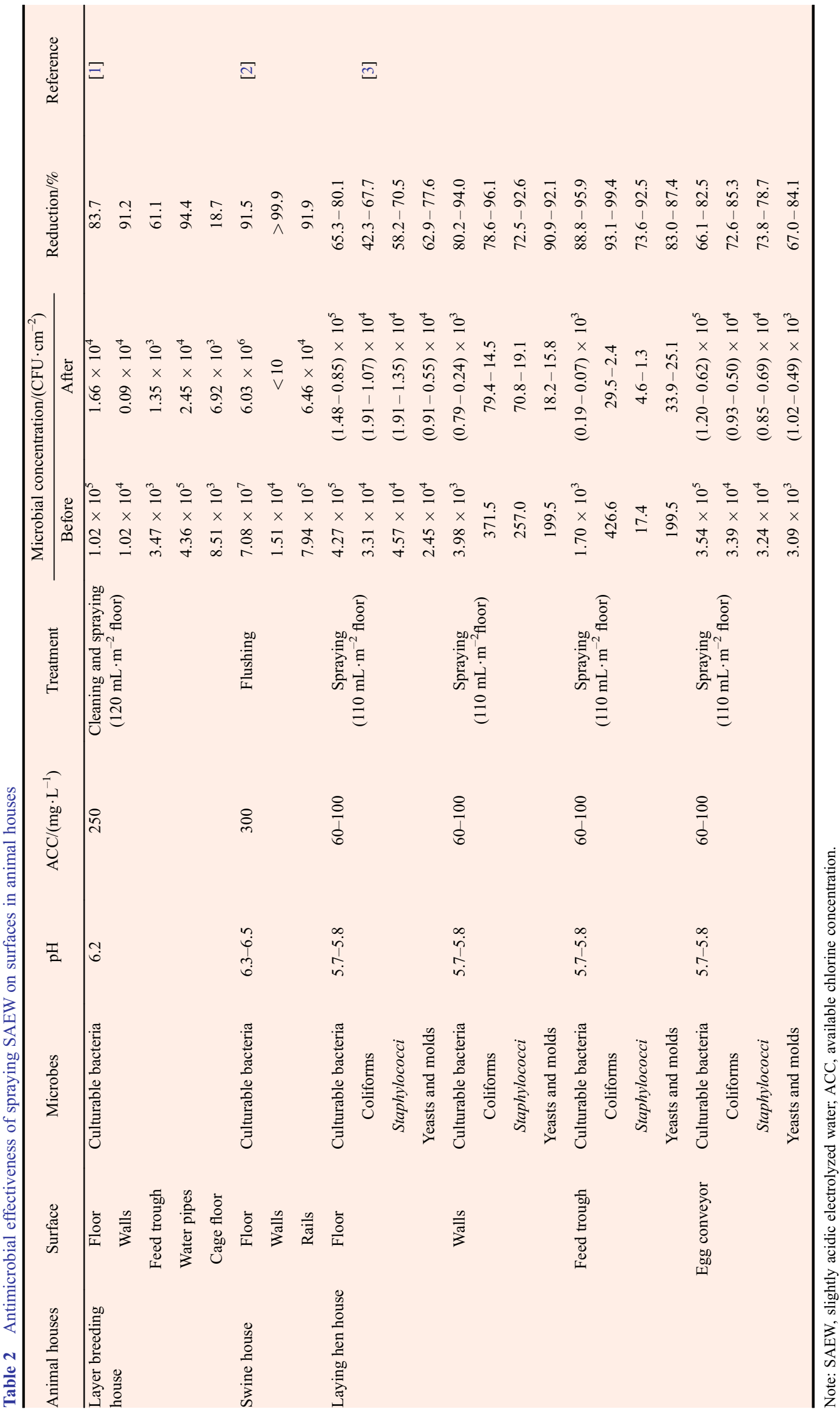




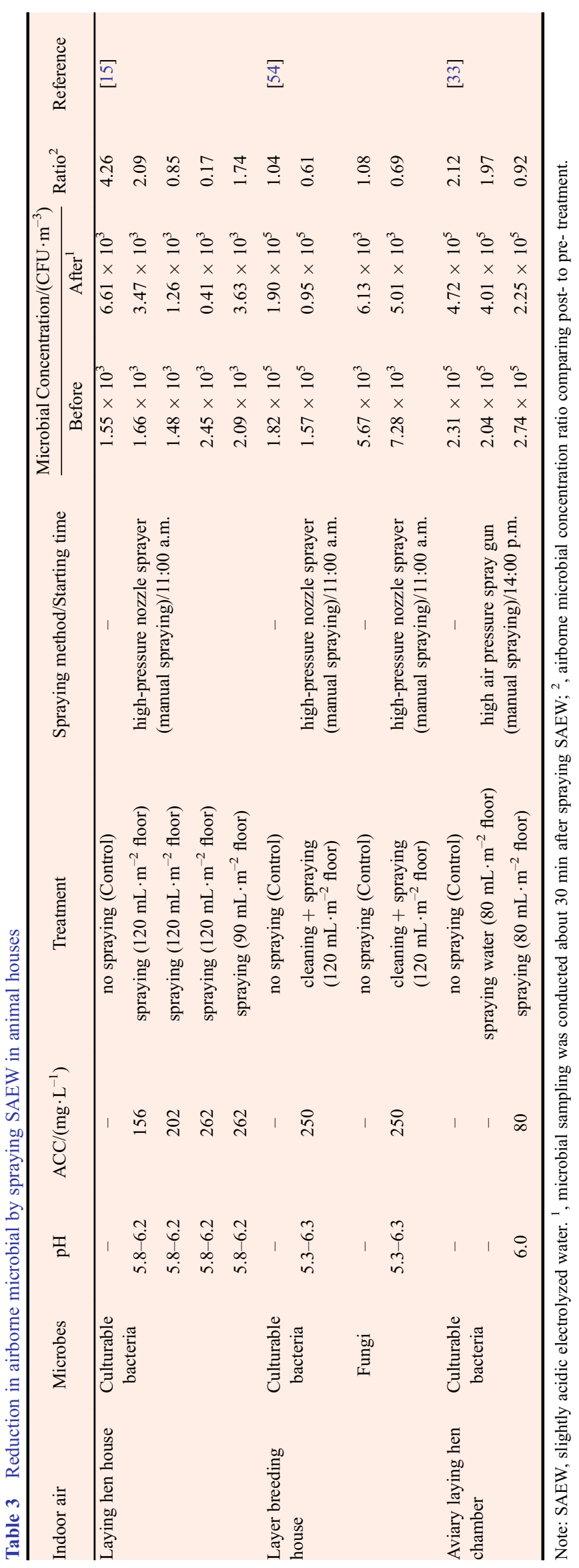


the size of sprayed aerosols and the ventilation can influence the inactivation efficiency of spraying SAEW or NEW on airborne microbes. Chuang et al. ${ }^{[75]}$ evaluated the inactivation efficiency of spraying NEW on $E$. coli and $B$. subtilis bacterial aerosols in a controlled environment chamber. The results indicated that spraying NEW is likely to be effective in inactivation of airborne bacterial contamination. Moreover, an increase in ventilation rate (air exchange rate $0.5-1.0$ per hour) and increase in aerosol count median diameter of sprayed aerosols $(0.12-0.2 \mu \mathrm{m})$ may facilitate the inactivation efficiency. Available chlorine loss caused by spraying is greatly dependent on the size of sprayed aerosols. The size of sprayed aerosols can also influence the gas-liquid contact, which is important for the probability of exposure of airborne microbes to sprayed SAEW or NEW aerosols. Smaller sprayed aerosols may promote the gas-liquid contact but cause greater loss of available chlorine during spraying. Zhao et al. ${ }^{[79]}$ reported an initial available chlorine loss of $11.7 \%-13.2 \%$ when spraying SAEW with an aerosol count median diameter of $80 \mu \mathrm{m}$. Our recent study evaluated the reduction efficiency of airborne culturable bacteria by spraying SAEW with different aerosol count median diameters in a controlled environment chamber. Spraying with medium size aerosols (count median diameter $=60$ $90 \mu \mathrm{m}$ ) is recommended for disinfection in animal houses. Spraying SAEW was also reported to be useful for scrubbing air exhausted from a poultry house by reducing ammonia and culturable bacteria ${ }^{[35,103]}$.

Spraying SAEW or NEW can destroy the microorganisms and slow their growth by direct contact with the microorganisms. However, the effect will reduce and vanish over time after spraying and the microbial populations both on the surfaces and in the air will increase again. Spraying SAEW can slow the increase of the microbial population in the air after spraying ${ }^{[15]}$. The remaining period for the effect of spraying SAEW or NEW has not been elucidated in current studies. It can be influenced by many factors such as ACC, spraying volume, size of sprayed aerosols, initial airborne microbial population, ventilation and management practices after spraying. Additionally, the surface and air disinfection in animal houses can have interactions. Microorganisms attached to the surfaces in animal houses can go into suspension in the air when they are disturbed by air-flow or animal activity. Also, airborne microorganisms can be attached to the surfaces from the air due to a series of processes such as gravitational sedimentation, impaction and electrostatic precipitation. Surface disinfection contributes to reducing the suspended microorganisms in the air after spraying. Also, air disinfection can lower the microbial population on the surfaces after spraying.

In summary, a large number of studies have revealed SAEW to be novel disinfection agents for both surface disinfection and air disinfection in animal houses. They represent alternative disinfection agents which are highly effective, healthy and environmentally friendly for the application in animal houses. AEW is not applied for disinfection in animal houses, due to its strong acidity which can cause severe corrosion and rapid $\mathrm{Cl}_{2}$ volatilization. More available chlorine exists as $\mathrm{HOCl}$ in SAEW compared to NEW, which means that SAEW will be more effective than NEW at the same ACC. This may explain why SAEW is more often employed for disinfection in animal houses than NEW. It is suggested that using SAEW with high ACC is best for reducing microbial populations in animal houses, due to their high level of organic matter. The system generating SAEW by electrolyzing dilute $\mathrm{NaCl}$ and $\mathrm{HCl}$ solutions in a non-membrane electrolytic cell is usually employed to produce SAEW for application in animal houses. This system not only produces SAEW with high ACC but also avoids the use of membranes in the electrolysis cell. Spraying SAEW is extensively applied for disinfection in animal houses, including surface and air disinfection. Spraying SAEW showed high antimicrobial activity on surfaces in animal houses and increasing the ACC of SAEW and the spraying volume can improve the antimicrobial effectiveness on these surfaces. Airborne microbial populations in animal houses can also be greatly reduced by spraying SAEW. The antimicrobial activity is influenced by ACC, spraying volume, size of sprayed aerosols, and ventilation of the building. Spraying SAEW can lower the microbial populations in animal houses, preventing animals and workers being exposed to high levels of pathogens.

\section{Conclusions}

EW exhibits strong antimicrobial activity against a broad spectrum of microorganisms. The definitions of SAEW and NEW are clarified in this review. SAEW and NEW can be produced by different systems, affecting their active components and thereby their antimicrobial activity. $\mathrm{HOCl}$ and $\mathrm{OCl}^{-}$are responsible for the antimicrobial activity of SAEW and NEW. Spraying SAEW is considered as an alternative approach for reducing the microbial populations in animal houses. Increasing the ACC of SAEW and the spraying volume could improve its antimicrobial effectiveness on the surfaces in animal houses. The airborne microbial population in animal houses can be greatly reduced by spraying SAEW. The airborne microbe reduction by spraying SAEW is influenced by ACC, spray volume, aerosols size and ventilation.

Acknowledgements This study was funded by the National Natural Science Foundation of China (30871957), Beijing Natural Science Foundation, China (6154029), and China Agricultural Research System (CARS-41).

Compliance with ethics guidelines Weichao Zheng, $\mathrm{Li} \mathrm{Ni}$, and Baoming 
Li declare that they have no conflicts of interest or financial conflicts to disclose.

This article is a review and does not contain any studies with human or animal subjects performed by any of the authors.

\section{References}

1. Hao X, Li B, Wang C, Zhang Q, Cao W. Application of slightly acidic electrolyzed water for inactivating microbes in a layer breeding house. Poultry Science, 2013, 92(10): 2560-2566

2. Hao X, Li B, Zhang Q, Lin B, Ge L, Wang C, Cao W. Disinfection effectiveness of slightly acidic electrolyzed water in swine barns. Journal of Applied Microbiology, 2013, 115(3): 703-710

3. Ni L, Cao W, Zheng W, Zhang Q, Li B. Reduction of microbial contamination on the surfaces of layer houses using slightly acidic electrolyzed water. Poultry Science, 2015, 94(11): 2838-2848

4. Whyte R T. Occupational exposure of poultry stockmen in current barn systems for egg production in the United Kingdom. British Poultry Science, 2002, 43(3): 364-373

5. Radon K, Danuser B, Iversen M, Monso E, Weber C, Hartung J, Donham K J, Palmgren U, Nowak D. Air contaminants in different European farming environments. Annals of Agricultural and Environmental Medicine, 2002, 9(1): 41-48

6. Andersen C I, von Essen S G, Smith L M, Spencer J, Jolie R, Donham K J. Respiratory symptoms and airway obstruction in swine veterinarians: a persistent problem. American Journal of Industrial Medicine, 2004, 46(4): 386-392

7. Heederik D, Sigsgaard T, Thorne P S, Kline J N, Avery R, Bonlokke J H, Chrischilles E A, Dosman J A, Duchaine C, Kirkhorn S R, Kulhankova K, Merchant J A. Health effects of airborne exposures from concentrated animal feeding operations. Environmental Health Perspectives, 2007, 115(2): 298-302

8. Zhao Y, Aarnink A J A, Groot Koerkamp P W G, Hagenaars T J, Katsma W E A, de Jong M C. Detection of airborne Campylobacter with three bioaerosol samplers for alarming bacteria transmission in broilers. Biological Engineering, 2011, 3 (4): $177-186$

9. Otake S, Dee S, Corzo C, Oliveira S, Deen J. Longdistance airborne transport of infectious PRRSV and Mycoplasma hyopneumoniae from a swine population infected with multiple viral variants. Veterinary Microbiology, 2010, 145(3-4): 198-208

10. Leach S A, Williams A, Davies A C, Wilson J, Marsh P D, Humphrey T J. Aerosol route enhances the contamination of intact eggs and muscle of experimentally infected laying hens by Salmonella typhimurium DT 104. FEMS Microbiology Letters, 1999, 171(2): 203-207

11. Hajmeer M, Ceylan E, Marsden J L, Fung D C. Impact of sodium chloride on Escherichia coli O157:H7 and Staphylococcus aureus analysed using transmission electron microscopy. Food Microbiology, 2006, 23(5): 446-452

12. Böhm R. Disinfection and hygiene in the veterinary field and disinfection of animal houses and transport vehicles. International Biodeterioration \& Biodegradation, 1998, 41(3-4): 217-224

13. Schmidt P L, O'Connor A M, McKean J D, Hurd H S. The association between cleaning and disinfection of lairage pens and the prevalence of Salmonella enterica in swine at harvest. Journal of Food Protection, 2004, 67(7): 1384-1388

14. Rodríguez Ferri E F, Martínez S, Frandoloso R, Yubero S, Gutiérrez Martín C B. Comparative efficacy of several disinfectants in suspension and carrier tests against Haemophilus parasuis serovars 1 and 5. Research in Veterinary Science, 2010, 88(3): 385-389

15. Zheng W, Kang R, Wang H, Li B, Xu C, Wang S. Airborne bacterial reduction by spraying slightly acidic electrolyzed water in a laying-hen house. Journal of the Air \& Waste Management Association, 2013, 63(10): 1205-1211

16. Sundheim G, Langsrud S, Heir E, Holck A L. Bacterial resistance to disinfectants containing quaternary ammonium compounds. International Biodeterioration \& Biodegradation, 1998, 41(3-4): 235-239

17. Lewis S, McIndoe A K. Cleaning, disinfection and sterilization of equipment. Anaesthesia and Intensive Care Medicine, 2004, 5(11): 360-363

18. Aarnisalo K, Salo S, Miettinen H, Suihko M L, Wirtanen G, Autio T, Lunden J, Korkeala H, Sjöberg A M. Bactericidal efficiencies of commercial disinfectants against Listeria monocytogenes on surfaces. Journal of Food Safety, 2000, 20(4): 237-250

19. Sidhu M S, Langsrud S, Holck A. Disinfectant and antibiotic resistance of lactic acid bacteria isolated from the food industry. Microbial Drug Resistance, 2001, 7(1): 73-83

20. Huang Y R, Hung Y C, Hsu S Y, Huang Y W, Hwang D F. Application of electrolyzed water in the food industry. Food Control, 2008, 19(4): 329-345

21. Hricova D, Stephan R, Zweifel C. Electrolyzed water and its application in the food industry. Journal of Food Protection, 2008, 71(9): 1934-1947

22. Rahman S M E, Khan I, Oh D H. Electrolyzed water as a novel sanitizer in the food Industry: current trends and future perspectives. Comprehensive Reviews in Food Science and Food Safety, 2016, 15(3): 471-490

23. Len S V, Hung Y C, Erickson M, Kim C. Ultraviolet spectrophotometric characterization and bactericidal properties of electrolyzed oxidizing water as influenced by amperage and $\mathrm{pH}$. Journal of Food Protection, 2000, 63(11): 1534-1537

24. Cui X, Shang Y, Shi Z, Xin H, Cao W. Physicochemical properties and bactericidal efficiency of neutral and acidic electrolyzed water under different storage conditions. Journal of Food Engineering, 2009, 91(4): 582-586

25. Guentzel J L, Liang Lam K, Callan M A, Emmons S A, Dunham V L. Reduction of bacteria on spinach, lettuce, and surfaces in food service areas using neutral electrolyzed oxidizing water. Food Microbiology, 2008, 25(1): 36-41

26. Deza M A, Araujo M, Garrido M J. Inactivation of Escherichia coli, Listeria monocytogenes, Pseudomonas aeruginosa and Staphylococcus aureus on stainless steel and glass surfaces by neutral electrolyzed water. Letters in Applied Microbiology, 2005, 40(5): 341-346

27. Abadias M, Usall J, Oliveira M, Alegre I, Vinâs I. Efficacy of neutral electrolyzed water (NEW) for reducing microbial contamination on minimally-processed vegetables. International Journal of Food Microbiology, 2008, 123(1-2): 151-158 
28. Koide S, Shitanda D, Note M, Cao W. Effects of mildly heated, slightly acidic electrolyzed water on the disinfection and physicochemical properties of sliced carrot. Food Control, 2011, 22(3-4): 452-456

29. Deza M A, Araujo M, Garrido M J. Efficacy of neutral electrolyzed water to inactivate Escherichia coli, Listeria monocytogenes, Pseudomonas aeruginosa, and Staphylococcus aureus on plastic and wooden kitchen cutting boards. Journal of Food Protection, 2007, 70(1): 102-108

30. Rahman S M E, Ding T, Oh D H. Effectiveness of low concentration electrolyzed water to inactivate foodborne pathogens under different environmental conditions. International Journal of Food Microbiology, 2010, 139(3): 147-153

31. Nan S, Wang C, Cao W, Li B. Disinfection effect and application of slightly acidic electrolyzed water in a dairy cattle farm. In: Proceedings of the 2010 ASABE Annual International Meeting. St. Joseph, Mich.: ASABE, 2010, Paper No. 1008926

32. Zheng W, Li B, Cao W, Zhang G, Yang Z. Application of neutral electrolyzed water spray for reducing dust levels in a layer breeding house. Journal of the Air \& Waste Management Association, 2012, 62(11): 1329-1334

33. Zheng W, Zhao Y, Xin H, Gates R S, Li B, Zhang Y, Soupir M L. Airborne particulate matter and culturable bacteria reduction from spraying slightly acidic electrolyzed water in an experimental aviary laying-hen housing chamber. Transactions of the ASABE, 2014, 57(1): 229-236

34. Bügener E, Kump A W S, Casteel M, Klein G. Benefits of neutral electrolyzed oxidizing water as a drinking water additive for broiler chickens. Poultry Science, 2014, 93(9): 2320-2326

35. Samani Majd A M, Kalbasi Ashtari A, Riskowski G L, Mukhtar S, Zhao L Y, Fang W. Electrolyzed water spray scrubber for removing ammonia from air. Transactions of the ASABE, 2015, 58 (4): 1069-1078

36. Hsu S Y. Effects of water flow rate, salt concentration and water temperature on efficiency of an electrolyzed oxidizing water generator. Journal of Food Engineering, 2003, 60(4): 469-473

37. Cao W, Zhu Z, Shi Z, Wang C, Li B. Efficiency of slightly acidic electrolyzed water for inactivation of Salmonella enteritidis and its contaminated shell eggs. International Journal of Food Microbiology, 2009, 130(2): 88-93

38. Koide S, Takeda J, Shi J, Shono H, Atungulu G G. Disinfection efficacy of slightly acidic electrolyzed water on fresh cut cabbage. Food Control, 2009, 20(3): 294-297

39. Ding T, Rahman S M E, Purev U, Oh D H. Modelling of Escherichia coli $\mathrm{O} 157: \mathrm{H} 7$ growth at various storage temperatures on beef treated with electrolyzed oxidizing water. Journal of Food Engineering, 2010, 97(4): 497-503

40. Issa-Zacharia A, Kamitani Y, Tiisekwa A, Morita K, Iwasaki K. In vitro inactivation of Escherichia coli, Staphylococcus aureus and Salmonella spp. using slightly acidic electrolyzed water. Journal of Bioscience and Bioengineering, 2010, 110(3): 308-313

41. Nan S, Li Y, Li B, Wang C, Cui X, Cao W. Effect of slightly acidic electrolyzed water for inactivating Escherichia coli $\mathrm{O} 157: \mathrm{H} 7$ and Staphylococcus aureus analyzed by transmission electron microscopy. Journal of Food Protection, 2010, 73(12): 2211-2216

42. Hao J, Liu H, Liu R, Dalai W, Zhao R, Chen T, Li L. Efficacy of slightly acidic electrolyzed water (SAEW) for reducing microbial contamination on fresh-cut cilantro. Journal of Food Safety, 2011, 31(1): 28-34

43. Pangloli P, Hung Y C. Efficacy of slightly acidic electrolyzed water in killing or reducing Escherichia coli O157:H7 on iceberg lettuce and tomatoes under simulated food service operation conditions. Journal of Food Science, 2011, 76(6): M361-M366

44. Issa-Zacharia A, Kamitani Y, Miwa N, Muhimbula H, Iwasaki K. Application of slightly acidic electrolyzed water as a potential nonthermal food sanitizer for decontamination of fresh ready-to-eat vegetables and sprouts. Food Control, 2011, 22(3-4): 601-607

45. Rahman S M E, Park J, Song K B, Al-Harbi N A, Oh D H. Effects of slightly acidic low concentration electrolyzed water on microbiological, physicochemical, and sensory quality of fresh chicken breast meat. Journal of Food Science, 2012, 77(1): 35-41

46. Zheng W, Cao W, Li B, Hao X, Ni L, Wang C. Bactericidal activity of slightly acidic electrolyzed water produced by different methods analyzed with ultraviolet spectrophotometric. International Journal of Food Engineering, 2012, 8(3): 41

47. Forghani F, Oh D H. Hurdle enhancement of slightly acidic electrolyzed water antimicrobial efficacy on Chinese cabbage, lettuce, sesame leaf and spinach using ultrasonication and water wash. Food Microbiology, 2013, 36(1): 40-45

48. Bodas R, Bartolomé D J, Tabernero De Paz M J, Posado R, García J J, Rodríguez L, Olmedo S, Martín-Diana A B. Electrolyzed water as novel technology to improve hygiene of drinking water for dairy ewes. Research in Veterinary Science, 2013, 95(3): 1169-1170

49. Hao X, Shen Z, Wang J, Zhang Q, Li B, Wang C, Cao W. In vitro inactivation of porcine reproductive and respiratory syndrome virus and pseudorabies virus by slightly acidic electrolyzed water. Veterinary Journal, 2013, 197(2): 297-301

50. Ni L, Cao W, Zheng W, Chen H, Li B. Efficacy of slightly acidic electrolyzed water for reduction of foodborne pathogens and natural microflora on shell eggs. Food Science and Technology Research, 2014, 20(1): 93-100

51. Mansur A R, Wang J, Park M S, Oh D H. Growth model of Escherichia coli $\mathrm{O} 157: \mathrm{H} 7$ at various storage temperatures on kale treated by thermosonication combined with slightly acidic electrolyzed water. Journal of Food Protection, 2014, 77(1): 23-31

52. Tango C N, Mansur A R, Kim G H, Oh D H. Synergetic effect of combined fumaric acid and slightly acidic electrolysed water on the inactivation of food-borne pathogens and extending the shelf life of fresh beef. Journal of Applied Microbiology, 2014, 117(6): 17091720

53. Tango C N, Wang J, Oh D H. Modeling of Bacillus cereus growth in brown rice submitted to a combination of ultrasonication and slightly acidic electrolyzed water treatment. Journal of Food Protection, 2014, 77(12): 2043-2053

54. Hao X, Cao W, Li B, Zhang Q, Wang C, Ge L. Slightly acidic electrolyzed water for reducing airborne microorganisms in a layer breeding house. Journal of the Air \& Waste Management Association, 2014, 64(4): 494-500

55. Forghani F, Park J H, Oh D H. Effect of water hardness on the production and microbicidal efficacy of slightly acidic electrolyzed water. Food Microbiology, 2015, 48: 28-34

56. Hao J, Li H, Wan Y, Liu H. Combined effect of acidic electrolyzed 
water (AcEW) and alkaline electrolyzed water (AlEW) on the microbial reduction of fresh-cut cilantro. Food Control, 2015, 50: 699-704

57. Mansur A R, Oh D H. Combined effect of thermosonication and slightly acidic electrolyzed water to reduce foodborne pathogens and spoilage microorganisms on fresh-cut kale. Journal of Food Science, 2015, 80(6): M1277-M1284

58. Horiba N, Hiratsuka K, Onoe T, Yoshida T, Suzuki K, Matsumoto T, Nakamura H. Bactericidal effect of electrolyzed neutral water on bacteria isolated from infected root canals. Oral Surgery Oral Medicine Oral Pathology Oral Radiology \& Endodontology, 1999, 87(1): $83-87$

59. Jadeja R, Hung Y C. Efficacy of near neutral and alkaline $\mathrm{pH}$ electrolyzed oxidizing waters to control Escherichia coli O157:H7 and Salmonella Typhimurium DT 104 from beef hides. Food Control, 2014, 41(41): 17-20

60. Audenaert K, Monbaliu S, Deschuyffeleer N, Maene P, Vekeman F, Haesaert G, De Saeger S, Eeckhout M. Neutralized electrolyzed water efficiently reduces Fusarium spp. in vitro and on wheat kernels but can trigger deoxynivalenol (DON) biosynthesis. Food Control, 2012, 23(2): 515-521

61. Posada-Izquierdo G D, Pérez-Rodríguez F, López-Gálvez F, Allende A, Gil M I, Zurera G. Modeling growth of Escherichia coli $\mathrm{O} 157: \mathrm{H} 7$ in fresh-cut lettuce treated with neutral electrolyzed water and under modified atmosphere packaging. International Journal of Food Microbiology, 2014, 177(7449): 1-8

62. Honda Y. Improvement of the electrolysis equipment and application of slightly acidic electrolyzed water for dairy farming. Journal of the Japanese Society of Agricultural Machinery, 2003, 65(1): 27-29

63. Ding T, Dong Q, Rahman S M E, Oh D H. Response surface modeling of Listeria monocytogenes inactivation on lettuce treated with electrolyzed oxidizing water. Journal of Food Process Engineering, 2011, 34(5): 1729-1745

64. Tomás-Callejas A, Martínez-Hernández G B, Artés F, ArtésHernández F. Neutral and acidic electrolyzed water as emergent sanitizers for fresh-cut mizuna baby leaves. Postharvest Biology and Technology, 2011, 59(3): 298-306

65. Hao J, Qiu S, Li H, Chen T, Liu H, Li L. Roles of hydroxyl radicals in electrolyzed oxidizing water (EOW) for the inactivation of Escherichia coli. International Journal of Food Microbiology, 2012, 155(3): 99-104

66. Park S H, Ha S D. Reduction of Escherichia coli and Vibrio parahaemolyticusccounts on freshly sliced shad (Konosirus punctatus) by combined treatment of slightly acidic electrolyzed water and ultrasound using response surface methodology. Food and Bioprocess Technology, 2015, 8(8): 1762-1770

67. Luo K, Oh D H. Inactivation kinetics of Listeria monocytogenes and Salmonella enterica serovar Typhimurium on fresh-cut bell pepper treated with slightly acidic electrolyzed water combined with ultrasound and mild heat. Food Microbiology, 2016, 53: 165171

68. Zhang C, Lu Z, Li Y, Shang Y, Zhang G, Cao W. Reduction of Escherichia coli O157: H7 and Salmonella enteritidis on mung bean seeds and sprouts by slightly acidic electrolyzed water. Food Control, 2011, 22(5): 792-796
69. Ding T, Xuan X, Li J, Chen S, Liu D, Ye X, Shi J, Xue S J. Disinfection efficacy and mechanism of slightly acidic electrolyzed water on Staphylococcus aureus in pure culture. Food Control, 2016, 60: 505-510

70. Gómez-López V M, Ragaert P, Ryckeboer J, Jeyachchandran V, Debevere J, Devlieghere F. Shelf-life of minimally processed cabbage treated with neutral electrolysed oxidising water and stored under equilibrium modified atmosphere. International Journal of Food Microbiology, 2007, 117(1): 91-98

71. Lee N Y, Kim N H, Jang I S, Jang S H, Lee S H, Hwang I G, Rhee M S. Decontamination efficacy of neutral electrolyzed water to eliminate indigenous flora on a large-scale of cabbage and carrot both in the laboratory and on a real processing line. Food Research International, 2014, 64(6): 234-240

72. Ratana-Arporn P, Jommark N. Efficacy of neutral electrolyzed water for reducing pathogenic bacteria contaminating shrimp. Journal of Food Protection, 2014, 77(12): 2176-2180

73. Afari G K, Hung Y C, King C H. Efficacy of neutral $\mathrm{pH}$ electrolyzed water in reducing Escherichia coli O157:H7 and Salmonella Typhimurium DT 104 on fresh produce items using an automated washer at simulated food service conditions. Journal of Food Science, 2015, 80(8): M1815-M1822

74. Deza M A, Araujo M, Garrido M J. Inactivation of Escherichia coli O157:H7, Salmonella enteritidis and Listeria monocytogenes on the surface of tomatoes by neutral electrolyzed water. Letters in Applied Microbiology, 2003, 37(6): 482-487

75. Chuang C Y, Yang S, Chang M Y, Huang H C, Luo C H, Hung P C, Fang W. Inactivation efficiency to Bacillus subtilis and Escherichia coli bacterial aerosols of spraying neutral electrolyzed water. Journal of the Air \& Waste Management Association, 2013, 63(12): 1447-1456

76. Monnin A, Lee J, Pascall M A. Efficacy of neutral electrolyzed water for sanitization of cutting boards used in the preparation of foods. Journal of Food Engineering, 2012, 110(4): 541-546

77. Vázquez-Sánchez D, Cabo M L, Rodríguez-Herrera J J. Single and sequential application of electrolyzed water with benzalkonium chloride or peracetic acid for removal of Staphylococcus aureus biofilms. Journal of Food Safety, 2014, 34(3): 199-210

78. Torlak E. Inactivation of Alicyclobacillus acidoterrestris spores in aqueous suspension and on apples by neutral electrolyzed water. International Journal of Food Microbiology, 2014, 185(33): 6972

79. Zhao Y, Xin H, Zhao D, Zheng W, Tian W, Ma H, Liu K, Hu H, Wang T, Soupir M. Free chlorine loss during spraying of membraneless acidic electrolyzed water and its antimicrobial effect on airborne bacteria from poultry house. Annals of Agricultural and Environmental Medicine, 2014, 21(2): 249-255

80. Xin C M, Zhao Y, Yao L, Wang W, Wang T. Stability and oxidizing effect of membraneless electrolyzed water. Journal of the American Oil Chemists' Society, 2015, 92(3): 371-381

81. Quan Y, Choi K D, Chung D, Shin I S. Evaluation of bactericidal activity of weakly acidic electrolyzed water (WAEW) against Vibrio vulnificus and Vibrio parahaemolyticus. International Journal of Food Microbiology, 2010, 136(3): 255-260

82. Chen T Y, Kuo S H, Chen S T, Hwang D F. Differential proteomics to explore the inhibitory effects of acidic, slightly 
acidic electrolysed water and sodium hypochlorite solution on Vibrio parahaemolyticus. Food Chemistry, 2016, 194(1): 529-537

83. Guentzel J L, Lam K L, Callan M A, Emmons S A, Dunham V L. Postharvest management of gray mold and brown rot on surfaces of peaches and grapes using electrolyzed oxidizing water. International Journal of Food Microbiology, 2010, 143(1-2): $54-60$

84. Tamaki S, Bui V N, Ngo L H, Ogawa H, Imai K. Virucidal effect of acidic electrolyzed water and neutral electrolyzed water on avian influenza viruses. Archives of Virology, 2014, 159(3): 405-412

85. Jeong J, Kim C, Yoon J. The effect of electrode material on the generation of oxidants and microbial inactivation in the electrochemical disinfection processes. Water Research, 2009, 43(4): 895-901

86. Jeong J, Kim J Y, Cho M, Choi W, Yoon J. Inactivation of Escherichia coli in the electrochemical disinfection process using a Pt anode. Chemosphere, 2007, 67(4): 652-659

87. Kim C, Hung Y C, Brackett R E. Roles of oxidation-reduction potential in electrolyzed oxidizing and chemically modified water for the inactivation of food-related pathogens. Journal of Food Protection, 2000, 63(1): 19-24

88. Liao L, Chen W, Xiao X. The generation and inactivation mechanism of oxidation-reduction potential of electrolyzed oxidizing water. Journal of Food Engineering, 2007, 78(4): 1326-1332

89. Koseki S, Yoshida K, Isobe S, Itoh K. Decontamination of lettuce using acidic electrolyzed water. Journal of Food Protection, 2001, 64(12): 652-658

90. McPherson L L. Understanding ORP's role in the disinfection process. Water Engineering and Management, 1993, 140(11): 2931

91. Park H, Hung Y C, Chung D. Effects of chlorine and $\mathrm{pH}$ on efficacy of electrolyzed water for inactivating Escherichia coli O157:H7 and Listeria monocytogenes. International Journal of Food Microbiology, 2004, 91(1): 13-18

92. Feliciano L, Lee J, Pascall M A. Transmission electron microscopic analysis showing structural changes to bacterial cells treated with electrolyzed water and an acidic sanitizer. Journal of Food Science, 2012, 77(4): M182-M187

93. Zeng X, Tang W, Ye G, Ouyang T, Tian L, Ni Y, Li P. Studies on disinfection mechanism of electrolyzed oxidizing water on $E$. coli and Staphylococcus aureus. Journal of Food Science, 2010, 75(5): M253-M260

94. Barrette W C Jr, Hannum D M, Wheeler W D, Hurst J K. General mechanism for the bacterial toxicity of hypochlorous acid: abolition of ATP production. Biochemistry, 1989, 28(23): 91729178

95. Hurst J K, Barrette W C Jr, Michel B R, Rosen H. Hypochlorous acid and myeloperoxidase-catalyzed oxidation of iron-sulfur clusters in bacterial respiratory dehydrogenases. European Journal of Biochemistry, 1991, 202(3): 1275-1282

96. Folkes L K, Candeias L P, Wardman P. Kinetics and mechanism of hydrochlorous acid reactions. Archives of Biochemistry and Biophysics, 1995, 323(1): 120-126

97. Fukuzaki S. Mechanisms of actions of sodium hypochlorite in cleaning and disinfection processes. Biocontrol Science and Technology, 2006, 11(4): 147-157

98. Zang Y, Li B, Bing S, Cao W. Modeling disinfection of plastic poultry transport cages inoculated with Salmonella enteritids by slightly acidic electrolyzed water using response surface methodology. Poultry Science, 2015, 94(9): 2059-2065

99. Oomori T, Oka T, Inuta T, Arata Y. The efficacy of disinfection of acidic electrolyzed water in the presence of organic materials. Analytical Sciences, 2000, 16(4): 465-469

100. Park E J, Alexander E, Taylor G A, Costa R, Kang D H. Effects of organic matter on acidic electrolyzed water for reduction of foodborne pathogens on lettuce and spinach. Journal of Applied Microbiology, 2008, 105(6): 1802-1809

101. Park E J, Alexander E, Taylor G A, Costa R, Kang D H. The decontamination effects of acidic electrolyzed water for Escherichia coli 0157:H7, Salmonella typhimurium, and Listeria monocytogenes on green onions and tomatoes with differing organic demands. Food Microbiology, 2009, 26(4): 386-390

102. Waters B W, Hung Y C. The effect of organic loads on stability of various chlorine-based sanitisers. International Journal of Food Science \& Technology, 2014, 49(3): 867-875

103. Zheng W, Li Z, Shah S, Li B. Removal of ammonia and airborne culturable bacteria by proof-of-concept windbreak wall with slightly acidic electrolyzed water spray for a layer breeding house. Applied Engineering in Agriculture, 2016, 32(3): 393-399 